\title{
HEALING ARCHITECTURE: DESAIN WARNA PADA KLINIK KANKER SURABAYA
}

\author{
Rahma Purisari \\ Universitas Pembangunan Jaya \\ rahma.purisari@upj.ac.id
}

\begin{abstract}
ABSTRAK. Arsitektur rumah sakit/ klinik merupakan bangunan fisik dimana dalam perancangannya didekati dengan indikator kenyamanan, keindahan, serta keberpihakan pada lingkungan, yang dapat membangun citra layanan kesehatan rumah sakit/ klinik itu sendiri. Pada kasus penyakit kanker, kondisi psikis pasien memiliki karakteristik cukup berbeda dengan pasien penyakit lainnya, yaitu tingkat kecemasan dan depresi yang cukup tinggi akan penyakitnya. Keberhasilan proses penyembuhan kanker tidak hanya ditentukan oleh kondisi fisiologis saja, tetapi juga kondisi psikologis. Dalam kaitannya dengan tujuan mengembalikan keseimbangan antara kondisi fisik dan psikologis pasien, maka isu healing architecture dipilih dengan warna sebagai komponennya pada Klinik Kanker yang berlokasi di Perumahan Citra Raya Surabaya. Berdasarkan studi literatur dan wawancara dengan pasien kanker, maka didapatkan bahwa warna hijau, biru, kuning, dan cokelat merupakan warna-warna yang dapat membantu proses penyembuhan pasien.
\end{abstract}

Proses desain pada rancangan ini menggunakan Design Development Spiral, dimana terdapat imaging, presenting, dan testing pada tahap perancangannya, sedangkan metode desain adalah dengan menggunakan alam sebagai cara untuk menghadirkan kreatifitas dalam arsitektur. Konsep rancangan dikaitkan dengan kriteria desain: warna sebagai representasi dari alam, warna sebagai elemen estetika, dan warna sebagai representasi dari material pembawanya, yang kemudian diwujudkan pada rancangan tapak, denah, bentuk dan facade bangunan, serta interior. Bangunan yang dihasilkan adalah sebuah Klinik Kanker dengan massa yang dipisahkan oleh void sebagai taman dan kolam yang terbuka dengan alam, serta ruang-ruang yang berorientasi pada warna yang diperoleh dari properti alam dimana pasien dapat mengakses alam tersebut dari dalam dan luar bangunan.

Kata kunci: healing architecture, klinik kanker, warna

ABSTRACT. Healthcare buildings are the physical buildings that have been approached with indicator of comfort, beauty, and in the context of environment. In the case of cancer, patient's psychological condition has quite different characteristic-the level of anxiety and depressions are quite high about this disease. The success of cancer curing process is not only determined by physiological conditions, but also the psychological state. In the aim of restoring the balance between physical and psychological condition, the healing architecture was selected with the color as its component in Cancer Clinic design located in Citra Raya Residence of Surabaya. Based on literature and interviews with cancer patients, it was found that green, blue, yellow, and brown are the colors that help the healing process.

Design process that has been used is Design Development Spiral, which have imaging, presenting, and testing on the stages, then the design method has used nature as a way to create architectural creativity. The design concept is connected to the design criterias: color as a representation of the nature, color as aesthetic elements, and color as a representation of its material, which are presented in the site plan, floor plan, form and building façade, and interior. The building form is separated by void as garden space and pond that blending with the nature and the treatment areas are oriented to the color taken from the nature's color properties. Thus, the patients could access those natures from inside and outside of the building.

Keywords: healing architecture, cancer clinic, color 


\section{PENDAHULUAN}

Healing adalah proses membangun kembali harmoni dalam diri individu dan merupakan hubungan timbal balik antara individu, keluarga, masyarakat, lingkungan, dan semangat hidup. Healing bukanlah proses mengobati, tetapi lebih kepada mengembalikan keseimbangan antara seluruh komponen tersebut. Jika tubuh sehat maka dapat diartikan bahwa terdapat keseimbangan, sebaliknya jika sakit maka tidak terdapat keseimbangan [1]. Terdapat temuan bahwa terdapat tingkat kecemasan karakteristik pasien kanker yang berbeda dari pasien dengan penyakit lain, sehingga kebutuhan untuk kehadiran lingkungan yang dapat mengurangi faktor stres selama periode pemulihan. Lingkungan yang menyembuhkan merupakan hasil desain yang ditunjukkan dengan adanya peningkatan positif atas kondisi fisik dan psikologis dari pasien, dokter, maupun pengunjung [2].

Hosking dan Haggard [3] mengemukakan komponen healing architecture antara lain: lansekap (taman) dan ruang diantara bangunan; interior, yang meliputi penutup lantai, dinding, langit-langit, wallpaper, cat, fabric, furnitur, noticeboards, pencahayaan, desain pintu dan jendela; material bangunan; seni dan dekorasi; faktor manusia, yang meliputi panca indera (pendengaran, penciuman, penglihatan, peraba, dan pengecap).

Warna diambil sebagai isu utama dalam perancangan karena warna merupakan bahasa jiwa yang mampu mempengaruhi suasana hati dan emosi kita. Warna memiliki dampak terhadap kesejahteraan manusia, dan dapat mengubah persepsi pandangan kita. Warna memiliki makna simbolik yang diakui oleh alam bawah sadar kita, yang mempengaruhi aliran dan jumlah energi dalam tubuh kita [4]. Hosking dan Haggard menyebutkan bahwa warna adalah interpretasi visual dari pigmen yang menyangkut semua material dan hanya dapat dilihat jika ada cahaya. Dengan demikian warna memiliki pengaruh pada volume, bentuk, ruang, dan perspektif. [3]

Menurut Gray, tidak ada satupun warna yang menjamin secara spesifik mampu memberikan dampak kesembuhan terhadap pasien [5]. Namun berdasarkan penelitian yang telah dilakukan, untuk menciptakan atmosfer yang mampu meningkatkan kenyamanan pasien terdapat warna-warna yang direkomendasikan untuk diaplikasikan pada interior suatu bangunan kesehatan. Begitu pula dengan Mahnke mengatakan bahwa warna harus diatur secara spesifik pada interior [6]. Warna mempunyai permainan psikologis dan estetis yang berbeda pada tiap ruang, dimana pada ruang tertentu terdapat warna-warna yang mampu menstimuli penyembuhan, memberikan keceriaan, serta meningkatkan konsentrasi pekerjaan bagi staf medis dan administrasi.

Tujuan desain adalah untuk mengembangkan desain skematik dari Klinik Kanker yang mampu mengeksplorasi warna sebagai cara untuk mendesain. Terdapat tiga kriteria desain untuk melakukan penelitian ini, yaitu (1) Warna sebagai representasi dari alam, dimana pasien dapat mengakses dan melihat warna langsung dari objek baik dari dalam ruang perawatan maupun di luar; (2) Warna sebagai estetika, dimana kolaborasi warna dengan komposisi tertentu digunakan dengan cara menempatkan sumbu, simetri, hirarki, ritme/ pengulangan, datum, transformasi, skala, keseimbangan; (3) Warna sebagai representasi dari material pembawanya, dimana pasien dapat mengakses alam baik secara langsung maupun representasi dari material pembawanya.

\section{METODE PERANCANGAN}

Rancangan ini menggunakan proses desain Zeisel yaitu: imaging, presenting, dan testing.[7]. Imaging adalah menawarkan suatu hal baru yang mampu memberikan kriteria seperti apa arsitektur kedepannya. Imaging dalam hal ini adalah segala sesuatu yang berkaitan dengan aspek psikologis, meliputi identifikasi masalah, pengumpulan data, analisis, dan sintesis. Masalah yang muncul adalah bagaimana menghadirkan warna-warna tertentu dalam sebuah desain yang secara psikologis mampu memberikan stimulus positif bagi kesehatan pasien. Ada empat pendekatan untuk mengumpulkan data: studi literatur, studi preseden, studi tapak, dan wawancara. Lokasi tapak adalah pada perumahan Citra Raya Surabaya, dimana fungsi tapak sesuai dengan yang direncanakan yaitu sebagai fasilitas umum. Lokasi ini mudah diakses karena terletak di jalan utama perumahan dengan bangunan eksisting adalah Rumah Sakit Ortopedi dan Traumatologi Surabaya. Imaging dilanjutkan dengan wawancara yang dilakukan dengan pasien kanker di Yayasan Kanker Indonesia, Surabaya. Tahap ini dilanjutkan dengan analisis untuk menetapkan kriteria desain, kebutuhan luasan ruang, karakter zona 

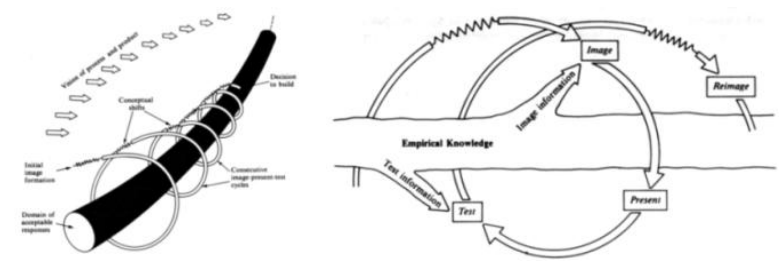

Gambar 1. Design Development Spiral (Zeisel, 1984)[7]

Presenting merupakan hasil dari kriteria yang diterapkan pada rancangan. Meskipun hasil yang diharapkan adalah tidak keseluruhan desain merupakan reaksi dari alam, namun sebagian besar metode ini digunakan untuk membentuk sebuah kreatifitas arsitektur. Dengan mengadaptasi metode Antoniades [8] maka metode yang digunakan dalam merancang Klinik kanker adalah sebagai berikut: (1) Memperhatikan konteks tapak terhadap lingkungan sekitarnya, melihat potensi untuk memberi bentuk sebuah rancangan tapak; (2) Memasukkan view di luar tapak yang dianggap baik ke dalam tapak, sehingga terbentuk hubungan outside-in dengan merancang bukaan jendela lebar, dengan tetap memperhatikan iklim tropis setempat; (3) Menginterpretasi alam dengan membuat kolam dan taman sebagai representasi lautan dan taman; (4) Merancang denah dengan memperhatikan kebutuhan pasien untuk selalu dapat mengakses alam, dengan menata area hijau, ketenangan langit, maupun hangat matahari berdekatan dengan area dimana pasien sebagian besar dirawat; (5) Mengimitasi elemen tiruan terhadap alam, baik material asli alam (bebatuan, kayu, rerumputan) maupun benda buatan manusia (wallpaper, cat, aplikasi warna alam pada furnitur) pada interior maupun eksterior; (6) Merancang bentuk bangunan dengan mengutamakan integrasi bangunan dengan alam, dengan cara menaik-turunkan dan melubangi pada beberapa bagian bangunan untuk dapat mengakses alam tersebut secara maksimal.

Testing merupakan evaluasi atas desain yang telah dihasilkan berdasarkan kriteria-kriteria, yang ketiganya dilakukan berdasar pengetahuan empiris. Testing dilakukan dengan verifikasi terhadap hasil wawancara dengan studi literatur dan evidence-based design mengenai kesesuaian antara warna- warna yang diinginkan oleh pasien dengan teori mengenai efek psikologis warna yang mampu memberikan penyembuhan. Testing dilanjutkan dengan mengomparasikan hasil desain klinik kanker dengan studi preseden, dengan tujuan mengetahui persamaan dan perbedaan dalam mendesain sebuah layanan kesehatan (tapak, denah, bentuk dan facade, dan interior) dalam kriteria warna sebagai representasi dari alam, warna sebagai elemen estetika, dan warna sebagai representasi dari material pembawanya.

\section{PEMBAHASAN}

\section{Rancangan Tapak}

Warna sebagai representasi dari alam ditunjukkan dengan menciptakan zona tenang (hijau dan zona biru) untuk memberikan kesempatan bagi pasien untuk menikmati area ruang luar bangunan sebanyak mungkin. Konsep zona hijau ditunjukkan dengan akses warna hijau dari sisi timur, sedangkan zona biru terletak di area selatan dengan menyediakan akses untuk menikmati warna langit, serta merancang kolam (sebagai representasi dari laut) yang dapat dinikmati oleh para pengunjung. Kolam dan juga berfungsi sebagai area transisi antara dalam dan luar bangunan.

Warna sebagai elemen estetika ditunjukkan dengan memberikan akses kepada pengunjung untuk menikmati estetika gerbang atau pintu masuk utama dari Perumahan Citra Raya. Dengan demikian pintu masuk utama bangunan ini terletak di sisi timur.

Warna sebagai representasi dari material pembawanya ditunjukkan dengan mengatur zona kuning dan cokelat di sisi utara dan barat. Zona cokelat ditempatkan di sisi barat karena area ini jarang digunakan atau dikunjungi oleh pasien. Zona kuning terletak di utara dan timur, 
berfungsi sebagai zona yang secara psikologis dapat memberikan semangat dan merangsang kreativitas, digunakan oleh tenaga medis dan administrasi. Bagian lain dari sisi timur

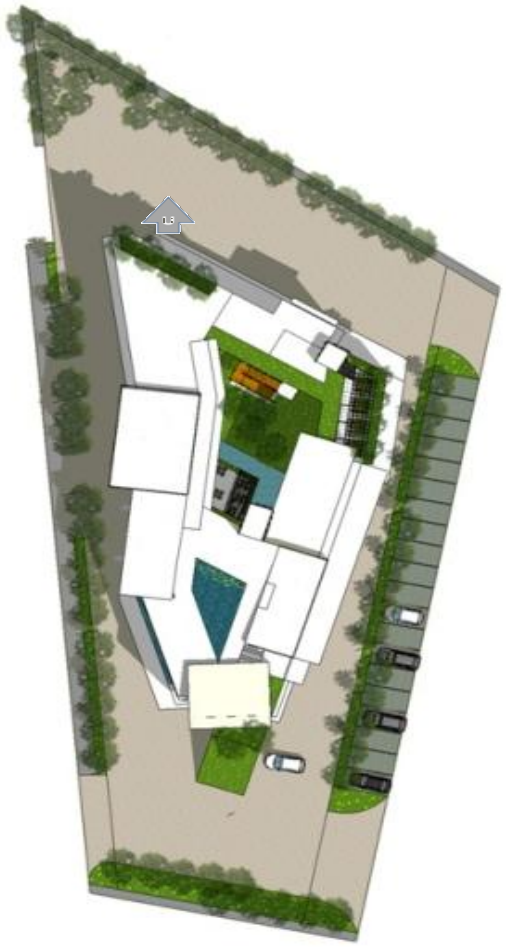

Gambar 2. Site Plan

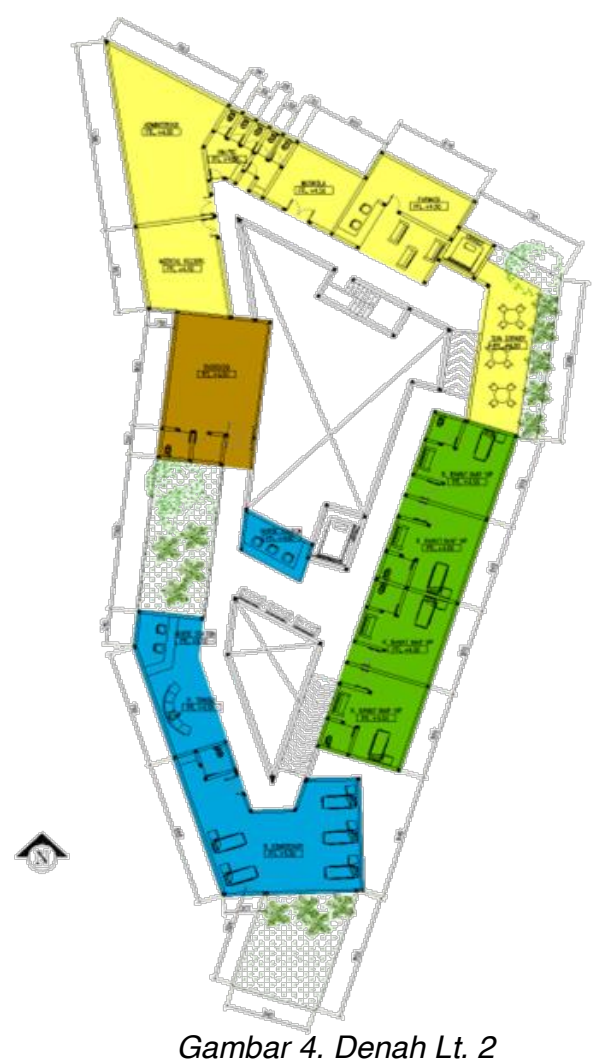

digunakan sebagai area sun corner, dimana pasien secara fisik dapat menikmati kehangatan sinar matahari.

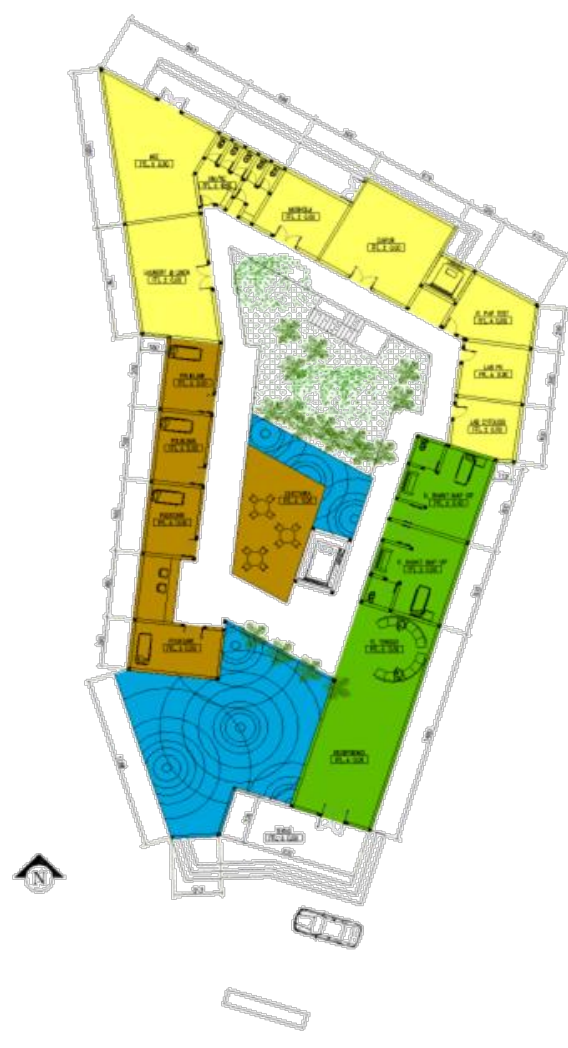

Gambar 3. Denah Lt. 1

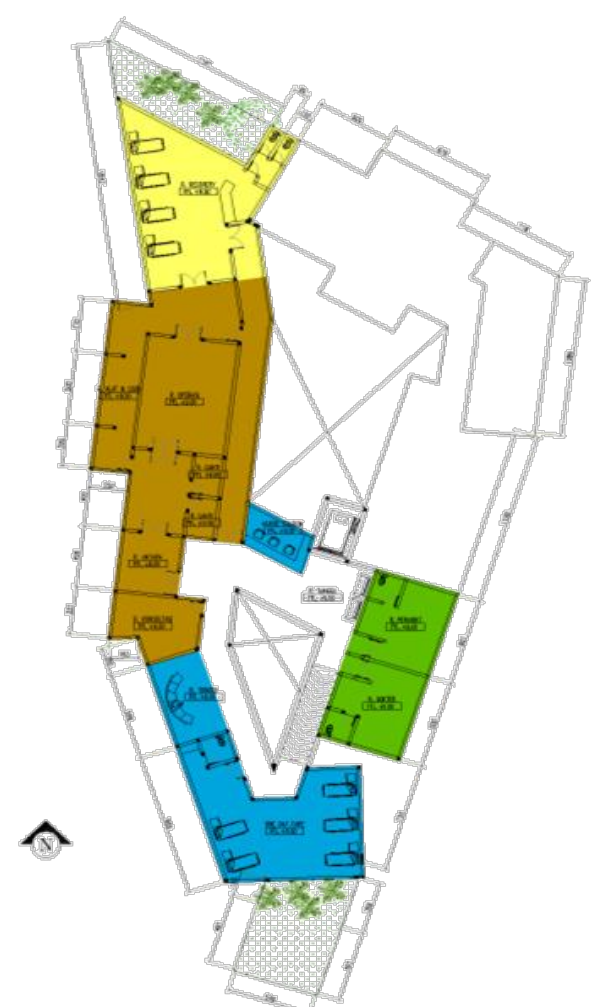

Gambar 5. Denarı Lt. 3 


\section{Denah}

Zona warna dibagi menjadi empat, yaitu hijau, biru, kuning, dan cokelat. Zona warna secara horisontal telah dijelaskan dalam rancangan tapak sedangkan zona secara vertikal diatur dengan menyesuaikan karakter, kebutuhan, dan korelasi antara ruang. Konsep warna untuk denah dihadirkan dengan memisahkan ruang satu dengan yang lain dengan koridor sebagai transisi. Luas total bangunan Klinik Kanker adalah $2.301,9 \mathrm{~m}^{2}$, terdiri dari fasilitas medis $\left(1.176,1 \mathrm{~m}^{2}\right)$, fasilitas non-medis $(171,6$ $\left.\mathrm{m}^{2}\right)$, fasilitas pendukung non medis $\left(426,4 \mathrm{~m}^{2}\right)$, area manajemen dan administrasi $\left(279,5 \mathrm{~m}^{2}\right)$, dan area servis $\left(248,3 \mathrm{~m}^{2}\right)$. Warna sebagai representasi dari alam disajikan dengan menciptakan kolam sebagai representasi warna biru yang dapat diakses oleh pasien, pengunjung, dan tenaga medis di lantai satu (a); sun corner dilengkapi dengan kursi, lantai parket kayu, taman vertikal, dan tanaman sebagai penghalang dari pandangan langsung luar sekaligus sebagai representasi dari kehangatan matahari yang secara psikologis memberikan semangat kepada pasien (b); warna hijau berupa taman mini sebagai vista (c); ruang recovery terletak di zona kuning sehingga pasien dapat menikmati hangatnya matahari yang secara psikologis mampu membangkitkan semangat mereka (d). Desain warna sebagai representasi dari alam dapat dilihat pada gambar 6 .

Tabel 1. Pengelompokan Ruang

\begin{tabular}{|c|c|c|c|c|c|c|c|c|c|c|}
\hline \multirow{2}{*}{ LANTAI } & \multicolumn{4}{|c|}{ ZONA WARNA } & \multicolumn{6}{|c|}{ ZONA KLINIK } \\
\hline & HIJAU & BIRU & KUNING & COKELAT & 1 & 2 & 3 & 4 & 5 & 6 \\
\hline 1 & $\begin{array}{l}\text { Entrance } \\
\text { Lobby } \\
\text { Resepsionis } \\
\text { Rawat Inap } \\
\end{array}$ & $\begin{array}{l}\text { Kolam } \\
\text { Ruang Tunggu }\end{array}$ & $\begin{array}{l}\text { Laboratorium } \\
\text { Area Servis }\end{array}$ & $\begin{array}{l}\text { Cafeteria } \\
\text { Poliklinik } \\
\text { Nurse Station }\end{array}$ & $\sqrt{ }$ & $\sqrt{ }$ & & $\sqrt{ }$ & & \\
\hline 2 & $\begin{array}{l}\text { Rawat Inap } \\
\text { Koridor } \\
\text { Nurse Station }\end{array}$ & $\begin{array}{l}\text { R. Kemoterapi } \\
\text { Ruang Tunggu } \\
\text { Nurse Station }\end{array}$ & $\begin{array}{l}\text { Sun Corner } \\
\text { Apotek } \\
\text { R. Administrasi } \\
\text { Rekam Medik } \\
\text { Area Servis }\end{array}$ & R. Radiologi & $\sqrt{ }$ & $\sqrt{ }$ & $\sqrt{ }$ & $\sqrt{ }$ & & \\
\hline 3 & $\begin{array}{l}\text { Staf Medik } \\
\text { Ruang Tunggu } \\
\text { Nurse Station }\end{array}$ & $\begin{array}{l}\text { One Day Care } \\
\text { Ruang Tunggu }\end{array}$ & R. Recovery & R. Operasi & $\sqrt{ }$ & & $\sqrt{ }$ & & $\sqrt{ }$ & \\
\hline
\end{tabular}

*catatan: Zona Klinik: (1) publik, (2) rawat inap, (3) rawat jalan, (4) servis, (5) ruang operasi, (6) staf

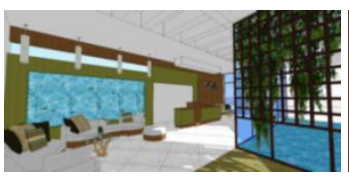

(a)

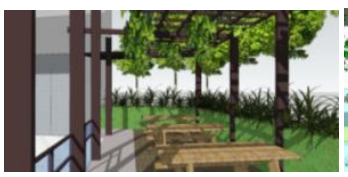

(b)

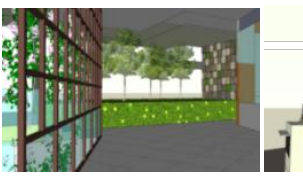

(c)

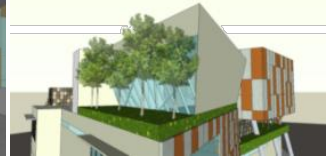

(d)

Gambar 6. Warna sebagai Representasi dari Alam pada Denah

Warna sebagai elemen estetika disajikan dalam komposisi warna hijau pada taman yang terintegrasi dengan kolam yang digunakan sebagai pembatas antara area hijau dan koridor (a); desain tanaman di muka bangunan difungsikan sebagai elemen estetika yang dapat diakses dari dalam kamar kemoterapi ke luar bangunan (b). (gambar 7)

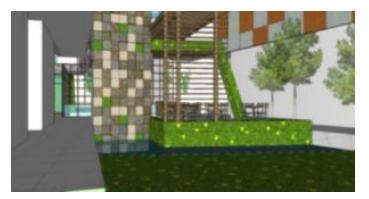

(a)

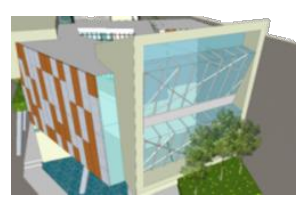

(b)

Gambar 7. Warna sebagai Elemen Estetika pada Denah

Warna sebagai representasi dari material pembawanya

ditunjukkan

dengan menempatkan kolam di lantai dasar sebagai representasi dari laut sekaligus sebagai 
pembatas pandangan antara luar dan dalam (a); area kemoterapi ditempatkan di sisi selatan untuk memaksimalkan perolehan sinar matahari di siang hari sekaligus menikmati warna biru langit (b). (gambar 8)

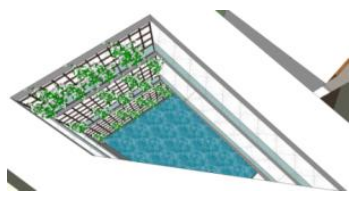

(a)

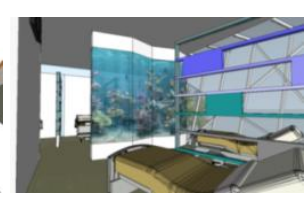

(b)

Gambar 8. Warna sebagai Representasi dari Material Pembawanya pada Denah

\section{Bentuk dan Facade Bangunan}

Bentuk dan façade bangunan adalah perwujudan dari desain warna dimana pasien, staf klinik dan pengunjung dapat mengakses warna yang ditentukan dari dalam dan luar bangunan. Dari luar, warna yang dipilih adalah putih tulang, cokelat, dan hijau. Warna putih pada façade secara psikologis mampu menciptakan kesan harmonis, elegan, dan kesederhanaan, sedangkan warna cokelat dirupakan dalam penggunaan kayu mosaik yang mampu memberikan kesan kesederhanaan dan kekuatan bangunan. Warna hijau berupa taman pada kanopi diletakkan di pintu masuk utama yang mampu memberikan kesan menyegarkan bagi pengunjung ketika memasuki bangunan.

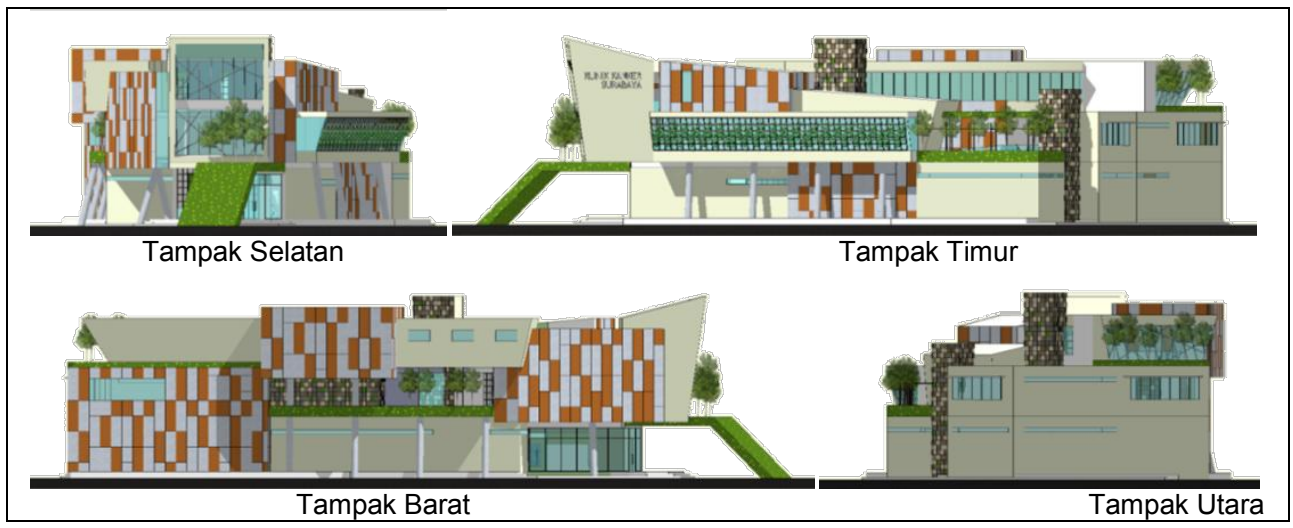

Gambar 9. Tampak Bangunan

Warna sebagai representasi dari alam disajikan dengan menciptakan gerbang masuk dengan taman atap yang mampu membawa warna hijau ke dalam façade (a); warna biru dirupakan sebagai dinding lebar pada sisi selatan ruang kemoterapi (b). (gambar 10). Warna sebagai elemen estetika disajikan dengan merancang one day care setenang mungkin untuk mendukung proses penyembuhan dengan bentuk langit-langit yang disusun horizontal (a); warna cokelat diaplikasikan pada facade bangunan dengan menggunakan kayu yang disusun bersama dengan kaca dalam bentuk mosaik (b). (gambar 11).

Warna sebagai representasi dari material pembawanya ditunjukkan dengan menghadirkan tanaman rambat di sepanjang balkon kamar rawat inap sehingga dapat dilihat langsung dari tempat tidur pasien (a); ruang kemoterapi (zona biru) dirancang dengan dinding lebar sebagai akses untuk menikmati taman dan langit biru, sekaligus horizontal blinds yang dirakit menjadi tirai untuk mengurangi sinar matahari yang berlebih (b). (gambar 12) 


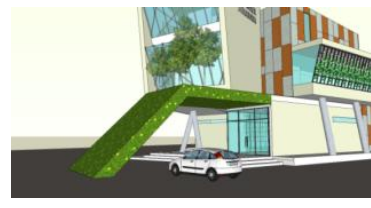

(a)

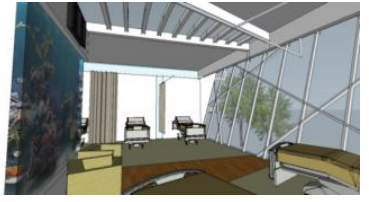

(b)

Gambar 10. Warna sebagai Representasi dari Alam pada Bentuk dan Facade

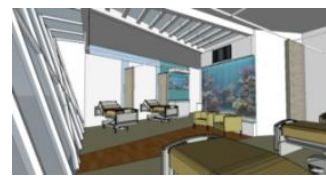

(a)

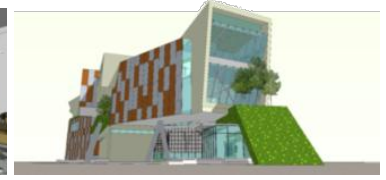

(b)

Gambar 11. Warna sebagai Elemen Estetika pada Bentuk dan Facade

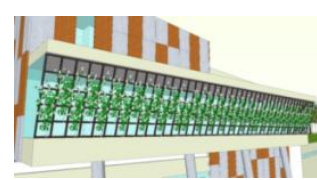

(a)

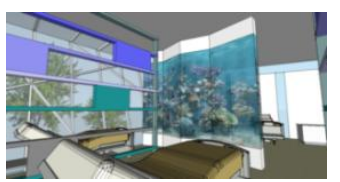

(b)

Gambar 12. Warna sebagai Representasi dari Material Pembawanya pada Bentuk dan Façade

\section{Interior}

Warna sebagai representasi alam disajikan dengan mengaplikasikan wallpaper bertema alam pada langit-langit ruang rekam medis (a); elemen kayu dan batu sebagai representasi dari warna cokelat disajikan di area kafetaria dengan bukaan lebar yang dapat diakses oleh pasien, tenaga medis dan pengunjung (b). Warna sebagai elemen estetika dihadirkan dengan menempatkan tanaman atau hiasan bunga sebagai aksen di ruang rawat inap yang didominasi dengan warna-warna monokrom (a); area resepsionis dirancang dengan mengaplikasikan material beludru sebagai representasi rumput (b); warna kuning secara psikologis dihadirkan pada ruang administrasi dengan menciptakan bukaan lebar agar pengguna dapat menikmati sinar matahari sekaligus pada furnitur dan pencahayaan dekorasi yang diharapkan dapat memberikan semangat dan mampu meningkatkan produktivitas kerja dari para staf administrasi (c). (gambar 14)

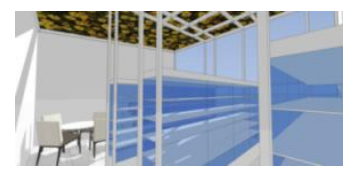

(a)

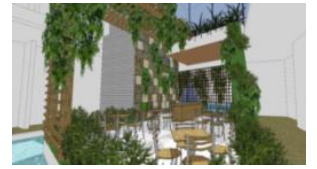

(b)

Gambar 13. Warna sebagai Representasi dari Alam pada Interior

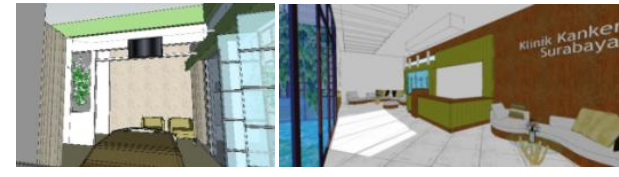

(a) (b)

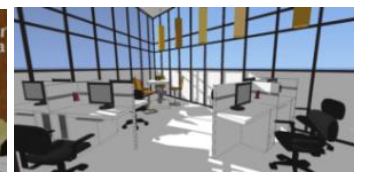

(c)

Gambar 14. Warna sebagai Elemen Estetika pada Interior 
Warna sebagai representasi dari material pembawanya disajikan dengan merancang kolam dan akuarium sebagai latar belakang area tunggu untuk mengalihkan perhatian pengguna dari kebosanan (a); warna cokelat sebagai representasi dari tanah dan hutan disajikan dengan mengaplikasikan parket di koridor (b); poliklinik (zona cokelat) merupakan zona pribadi dimana pasien tidak dapat mengakses alam dari dalam ruangan, dengan demikian ornamen batu diterapkan di ruangan ini (c). (gambar 15)

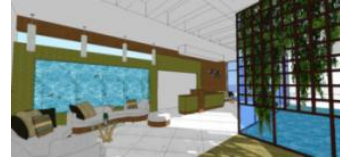

(a)

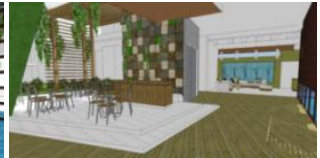

(b)

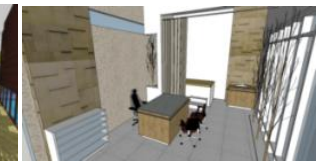

(c)

Gambar 15. Warna sebagai Representasi dari Material Pembawanya pada Interior

\section{KESIMPULAN}

Pembahasan dan hasil desain di atas menunjukkan bahwa lingkungan fisik merupakan hal penting dalam proses penyembuhan, sehingga semakin jelas bahwa healing architecture harus mampu memberikan solusi dalam mengembalikan keseimbangan antara kondisi fisik dan psikologis pasien. Kebutuhan non-medis dapat dipenuhi dengan mengubah lingkungan menjadi suasana yang mampu mengalihkan perhatian pasien akan penyakit yang dideritanya dengan menghadirkan lingkungan yang ramah terhadap semua pengguna yang terlibat (pasien, keluarga, staf medis, dan non-medis).

Selama ini persepsi orang terhadap warna hanya sebatas memberikan suasana hati dan efek psikologis tertentu yang dapat diterapkan pada interior bangunan. Namun penelitian desain ini membuktikan bahwa warna dapat mempengaruhi bentuk hingga susunan ruang di dalam maupun luar bangunan. Komposisi dan konsep penggunaan warna tertentu di Klinik Kanker didasarkan pada alasan untuk mengakses warna yang dibutuhkan untuk memberikan kesembuhan psikis terhadap pasien kanker. Hijau, biru, kuning, dan cokelat adalah warna yang mampu mendukung proses penyembuhan yang disajikan dalam kriteria warna sebagai representasi dari alam, warna sebagai elemen estetika, dan warna sebagai representasi dari material pembawanya. Dengan desain yang dihasilkan, maka pasien akan dapat merasakan perbedaan suasana di Klinik Kanker ini, sehingga secara psikologis mendapatkan energi positif untuk membangkitkan semangat mereka dari perasaan yang tidak nyaman.

\section{REFERENSI}

[1] Stark, Alex. (2009). Buildings that Heal: Energetic Criteria in the Design of Healing Environments. http://www.alexstark.com. Accessed November, 272011.

[2] Hamilton, D.K. and Watkins, David H. (2009). Evidence-based design: For multiple building types. New Jersey: John Wiley \& Sons Inc.

[3] Hosking, Sarah and Haggard, Liz. (1999). Healing the Hospital Environment: Design, Management, and Maintenance of Healing the Hospital Environment. New York: E \& FN Spon.

[4] Pile, John F. (1995). Interior Design. New York: Abrams Inc.

[5] Novak, Celeste A. and Richardson, Barbara (2012, September). Functional Color and Design in Healthcare Environment: Color and nature provide healing benefits in hospital setting. Architectural Record. New York: McGraw Hill,.

[6] Mahnke, Frank H. (1996). Color, Environment, and Human Response. New York: John Wiley Sons Inc.

[7] Zeisel, John. (1984). Inquiry by Design: Tools for Environment-Behavior Research. Cambridge: Cambridge University Press.

[8] Antoniades, Anthony C. (1992). Poetics of Architecture: Theory of Design. New York: John Wiley \& Sons.

[9] Ulrich, Roger S. (1984). "View through a Window May Influence Recovery from Surgery". Science. New Series, Vol. 224, hal $420-421$. 